\title{
A Sequential Explanatory Investigation of TPACK: Malaysian Science Teachers' Survey and Perspective
}

\author{
You Eng Chieng and Choon Keong Tan
}

\begin{abstract}
Like several other countries, Malaysia sees information and communications technology (ICT) as a potential tool for improving education quality. However, there is a shortage research examining the knowledge of Malaysia secondary school teachers in science ICT integration. Therefore, this study aims to investigate the secondary science teachers of Malaysia at exploring their perceptions of ICT integration regarding Technological Pedagogical Content Knowledge (TPACK), which focused on quantitative findings supported by qualitative findings. This sequential explanatory approach aims to examine the views of science teachers regarding technology integration with respect to TPACK. The study included 219 survey respondents and 3 interview participants. For the quantitative data analysis, descriptive statistics and multiple regression were used, while a thematic method was performed for the qualitative data analysis. The results indicate that the understanding of science teachers regarding their technology-based knowledge is lower than that of non-technology awareness, both pedagogical and content awareness. Furthermore, interview results show about the technology integration related to TPACK, namely, type of ICT used, pedagogy of teaching, content knowledge and the purpose of ICT integration. The results address implications for professional development and programme accreditation for the secondary school science teachers.
\end{abstract}

Index Terms-Science teachers, TPACK, Integration of ICT.

\section{INTRODUCTION}

The application of technology in teaching and learning has been said to be a major concern in twenty-first-century schools [1] and has earned awareness of different groups such as the International Society for Education Technology and the Southeast Asian Ministries of Education (SEAMEO). A study released by SEAMEO in 2010 revealed that Malaysia is one of the countries that has not fully implemented technological integration in the education system. This result is further emphasized by the findings of [2] who reported low rates of teachers' integration of ICT, despite having a positive perception of ICT's integration in education and learning.

Teachers are widely believed to play a significant role in integrating ICT into the classroom. Although earlier work on ICT integration has concentrated mainly on the outcome of the students [3], more recent studies have shifted emphasis to the creation of their awareness by teachers [4], [5]. Today's teachers, including science teachers, acknowledged that technical skills alone did not contribute well to the learning

Manuscript received October 1, 2020; revised March 20, 2021.

The authors are with the Faculty of Psychology and Education, University of Malaysia Sabah, Jalan UMS, 88400, Kota Kinabalu, Sabah, Malaysia (e-mail: yechieng@gmail.com, e-mail: cktanums@gmail.com). promotion of students without teachers knowing how to use technology in meaningful ways relevant to the aspects of pedagogy and subject matter. Therefore, the focus of education technology studies has shifted from merely teaching technology skills to effectively integrating technology into teaching.

In 2006, Mishra and Koehler introduced the concept of Technological Pedagogical Content Knowledge (TPACK) in the education system. Many researchers have recognised this paradigm as having an impact on the use of technology in pedagogy across the content construct. Thus, this concept has gained interest from educators in recent years. According to [6], a successful teacher in the twenty-first century needs to know how to incorporate technology into teaching, particularly in the integration of technology into the teaching and including the science subjects [7], [8]. The TPACK framework is said to be a branch of knowledge that is applicable to teachers' ability that incorporates technology into the classroom [9]. This framework can be used to define the perceptions of teachers in different information dimensions and can also be used to determine the teachers' needs for professional development [10].

Although a burgeoning interest in TPACK has been noted by researchers [11], [12], it seems evident that there has been a small number of publications reporting on this topic for developing countries, including Malaysia. Very few studies have been conducted to assess the level of TPACK teachers in Malaysia as one of the developing countries. For example, study by [13] focuses on the perception of TPACK mathematics teachers, while the study by [14] included primary science teachers in the schools. As a result, the need for research into the TPACK teacher investigation in Malaysia has been established. Therefore, this study sought to fill the literature gap as far as TPACK is concerned for Malaysia, focusing specifically on science teachers. The paper was guided by the following questions:

1) What is Malaysia science teachers' level of the TPACK?

2) How do the constructs on the TPACK framework correlate with the integration of ICT?

3) Which of the constructs on the TPACK framework is the major predictor of integration of ICT?

\section{LITERATURE REVIEW}

\section{A. The TPACK}

Technology integration planning is the use of technology resources in education in the general subject field to prepare a lesson to help students become engaged twenty-first-century learners. Science teachers present today are possibly the 
teachers who can apply suitable science knowledge strategies to achieve effective technology teaching. To effectively use technology to support the education, teachers should have appropriate technological knowledge, pedagogical knowledge and expertise of content and should also understand the interaction between these categories of knowledge. Thus, one well-known method is TPACK, developed by [9], which is based firstly on the Pedagogical Content Knowledge (PCK) of [15], to assess the understanding of technology integration into teaching. They had stressed the needs of teachers to put in technological knowledge, pedagogical knowledge and expertise of content, as shown in Diagram 1.

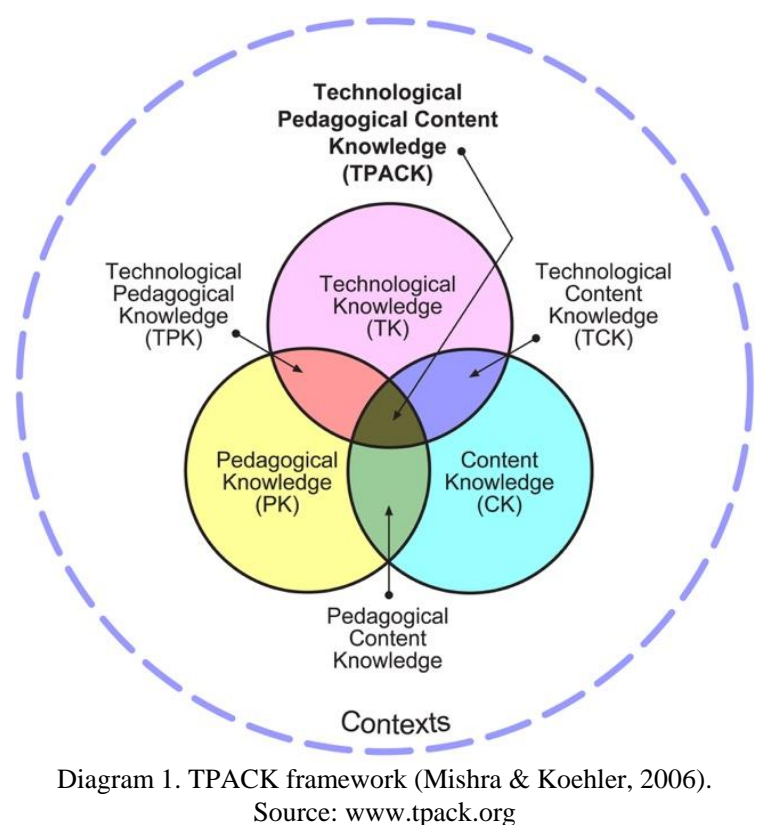

The well-known Venn diagram shown in Diagram 1 depicts three basic constructs of TPACK, namely, Technological Knowledge (TK), Pedagogical Knowledge (PK) and Content Knowledge (CK). The intertwined constructs (four constructs) of the knowledge model are understood to be distinct constructs essential of the basic knowledge constructs, namely, Technological Content Knowledge (TCK), Technological Pedagogical Knowledge (TPK), Pedagogical Content Knowledge (PCK), as well as TPACK. This framework has been widely adopted and adapted by the educational application of ICT researchers from time to time [16], [17], including pre-service teachers [18], [19], in service teachers [12] and even the lectures in higher education institute [20]. Therefore, the value of TPACK studies needs to be conducted from time to time, and inconsistencies between countries due to the differences of technology education policies- must be addressed. In addition, enhancing the teachers' TPACK development is also important for various research populations, including science teacher education.

It has been recommended that integration of ICT for instruction can improve science teaching and learning process [21]. In the review of research trends in TPACK, [22] found that almost half of the empirical TPACK studies focused on teachers' domain-general TPACK, and relatively fewer studies explored teachers' domain-specific TPACK.
Science $(15.9 \%)$ was found to be one of the major subject domains that were explored in those domain-specific TPACK studies. This is possibly because science is comparatively more abstract for students, and science teachers will have a greater chance of adopting technology to help students resolve their learning difficulties.

Regardless of the type or quantity of technology, classroom teachers are still the key to facilitating educational reform with ICT. Several appeals about science teacher education technologies have revealed the need for more in-depth investigations [23], [24]. According to [11], technology has been emphasized to enhance the learning of the concepts in science and as a strong tool of supporting learner's activities. In such condition, science teachers must be trained with related knowledge to integrate ICTs in instructional activities.

\section{Methodology}

The study of mixed methods, sequential explanatory design, is conducted to investigate a study phenomenon involving some data sources and to establish the reliability and validity of the findings [25]. Sequential explanatory design is focused on quantitative data supported by qualitative data for analysis purposes [25]. The study was conducted in one of the states in Malaysia for about 3 months. This study began with a quantitative process, followed by the collection and analysis of qualitative data. We used two types of data sources, survey and interview, to answer questions for this research. A survey was used because surveys can gather data at a particular point in time with the intention of describing the nature of existing conditions [26]. This is followed interviews to obtain in-depth information in relation to the technology integration in for their teaching subject, i.e. science.

\section{A. Quantitative}

This study includes 454 secondary school science teachers in the northern zone district in Sarawak, Malaysia. A simple random sampling was used to select the appropriate number of participants. Thus, printed questionnaires had been distributed to 250 science teachers, where 228 instruments were returned and 9 instruments were not able to calculate; some statements were not answered by the respondents (see Table I). In considering and identifying a suitable survey instrument to investigate Malaysian science teachers' level of TPACK and integration of ICT, the survey was made possible through the development of a questionnaire whose items were adopted and adapted from among [27] and [28] surveys for assessing TPACK. While the questionnaire for assessing integration of ICT is based of TIP model [29]. Existing surveys were used because for a complex and multidimensional variable, it is appropriate to use an existing instrument if one exists [30]. However, the items on these surveys were not used without due critique and evaluation. Some items were modified to suit the focus of this research, while others were as they were used originally in previous studies.

There were 42 items included in the 7 constructs of TPACK: 8 items of TK, 6 items of PK, 6 items of CK, 5 items 
of Technological Pedagogical Knowledge (TPK), 6 items of TCK, 6 items of PCK and 5 items of TPACK. In addition, there were 26 items for the instrument for the integration of ICT. The internal consistencies of the items of the various constructs were determined with the Cronbach alpha reliability coefficient. The reliabilities for the various items were $\mathrm{TK}=0.91, \mathrm{PK}=0.92, \mathrm{CK}=0.91, \mathrm{TPK}=0.93, \mathrm{TCK}=$ $0.94, \mathrm{PCK}=0.88$, TPACK $=0.92$ and integration of ICT $=$ 0.92 .

Three experts validated the instruments for content validity before being distributed. In addition, translation experts were involved since some survey items were translated from English to Bahasa Malaysia. The questionnaires were distributed with the help from selected school administration or head of science departments. After the data collection, all the data were calculated, and their mean and standard deviation were measured to investigate the teachers' TPACK level. Multiple regression were conducted. Integration of ICT was the dependent variable, while TK, PK, CK, TPK, TCK, PCK and TPACK were the independent variables throughout both scenarios.

TABLE I: SURVEY RESPONDENTS' INFORMATION

\begin{tabular}{lcc}
\hline \hline Total Instruments & Number & Percentages (\%) \\
Distributed & 250 & 100 \\
Returned & 228 & 91.2 \\
Incomplete answers & 9 & 3.6 \\
Used for analysis & 219 & 87.6 \\
\hline \hline
\end{tabular}

\section{B. Qualitative}

The interviews were conducted in order to obtain in-depth information of their teaching subject, i.e. science, regarding technology integration. The interviews took place in Bahasa Malaysia with a duration of 25-30 min. All the names of the participants were replaced with pseudonyms for ethical consideration, in order to ensure secure enforcement of human rights. The decision of science teachers to be in the study for the interview sessions was voluntary, and they had submitted informed consent forms.

A researcher had interviewed three participants one by one and did the transcription of the data after that. A researcher analysed the transcriptions and classified them into thematic products. This cycle was repeated until the last participant. The relevant chunks of statements had been marked up and put in permanent categories [25]. The verbatim transcription statements were accompanied by participant screening procedures for the study's trustworthiness [25]. The checking procedures were done by providing the participant with the interview data in order to get their feedback and agreement. This move was taken with a view to reducing the study bias. Lastly, the participants agreed to present the study results.

\section{FINDINGS}

\section{A. TPACK Level of Science Teachers'}

Firstly, the seven constructs of TPACK were separately calculated for the mean and standard deviation (see Table II). The highest score of the constructs of the survey was CK (mean $=3.94, \mathrm{SD}=0.68$ ). This is followed by the PK and
PCK constructs, both gaining the second and third higher mean scores of TPACK perceived by science teachers (mean $=3.93, \mathrm{SD}=.56 ;$ mean $=3.86, \mathrm{SD}=.64)$. All technological-based knowledge constructs had lower mean scores: TK $($ mean $=3.13, \mathrm{SD}=.66)$, TPK $($ mean $=3.60, \mathrm{SD}=$ $0.060)$, TCK $($ mean $=3.56, \mathrm{SD}=0.63)$ and TPACK $($ mean $=$ $3.60, \mathrm{SD}=0.65)$. At the same time, the Cronbach alpha ranges from 0.89 to 0.94 which is considered good and excellent based on the strength using rule of thumb by [31].

\begin{tabular}{lccc} 
TABLE II: LEVEL OF TPACK OF SCIENCE TEACHERS (N = 219) \\
\hline \hline Constructs & $\begin{array}{l}\text { Mean } \\
\text { Score }\end{array}$ & S.D & $\begin{array}{c}\text { Cronbach } \\
\text { Alpha }(\boldsymbol{\alpha})\end{array}$ \\
\hline TK & 3.13 & 0.66 & 0.91 \\
PK & 3.93 & 0.56 & 0.92 \\
CK & 3.94 & 0.68 & 0.91 \\
TPK & 3.60 & 0.60 & 0.93 \\
TCK & 3.56 & 0.63 & 0.94 \\
PCK & 3.86 & 0.64 & 0.89 \\
TPACK & 3.60 & 0.65 & 0.92 \\
\hline \hline
\end{tabular}

\section{B. Correlation among TPACK Constructs with Integration of ICT}

The second research question sought to find constructs of the TPACK framework correlate with the integration of ICT. Significant correlations were observed between all the constructs of TPACK with integration of ICT. The strongest correlation was between the construct of TPACK and the integration of ICT. This is followed by the construct of TCK, TPK, TK, PCK, CK and lastly PK. Table III summarises the correlation results.

TABLE III: CORRELATION RESULTS FOR THE TPACK CONSTRUCTS WITH THE INTEGRATION OF ICT

\begin{tabular}{cc}
\multicolumn{2}{c}{ THE INTEGRATION OF ICT } \\
\hline Integration of ICT \\
TK & $.464^{* * *}$ \\
PK & $.376^{* *}$ \\
CK & $.380^{* *}$ \\
TPK & $.626^{* *}$ \\
TCK & $.665^{* * *}$ \\
PCK & $.463^{* *}$ \\
TPACK & $.668^{* * *}$ \\
\hline \hline
\end{tabular}

\section{Prediction of the Contributions of the Various Constructs to Integration of ICT}

Since TPACK is the contributing construct, a standard multiple regression was performed to determine which independent variable was the integration of ICT's largest predictor, while all the other variables were taken into account. The standard multiple regression with the seven independent predictors (TK, CK, PK, PCK, TCK, TPK and TPACK) to predict the integration of ICT revealed that the TPACK and TCK constructs accounted for $48.2 \%$ of the 
variance (adjusted $\mathrm{R}^{2}=0.482$ ). The adjusted $\mathrm{R}^{2}$ was stated because the $\mathrm{R}$ square might overestimate its true value in the population if the sample size is small [32]. This will produce a better predictor of the true population value after the adjusted $\mathrm{R}$ square corrects the value of $\mathrm{R}$ square. Thus, the overall multiple regression was statistically significant. Table IV presents the summary of the model.

The regression analyses indicated that the constructs of TPACK and TCK were the significant contributors to the integration of ICT. These constructs accounted for over $40 \%$ of the variance in integration of ICT. Although the construct of TPACK was the single largest contributor, the stepwise regression indicated that the construct of TCK also made a significant contribution to the variance in the model. Again, the combined effect of the two predictors (TPACK and TCK) raised the variance of integration of ICT accounted for by the predictors from $44 \%$ to $48 \%$.

\begin{tabular}{lcccccc}
\multicolumn{7}{c}{ TABLE IV: STEPWISE REGRESSION RESULTS } \\
\hline \hline Model & $\mathbf{B}$ & $\begin{array}{c}\text { Standard } \\
\text { Error }\end{array}$ & Beta & $\mathbf{R}$ & $\mathbf{R}^{2}$ & $\begin{array}{c}\text { Adjusted } \\
\mathbf{R}^{2}\end{array}$ \\
\hline (Constant) & 1.204 & .161 & & & & \\
TPACK & .317 & .074 & .372 & $.678^{a}$ & .446 & .443 \\
TCK & .317 & .076 & .359 & $.697^{b}$ & .487 & .482 \\
\hline \hline
\end{tabular}

$p<.05$

\section{Perceived Integration of ICT Related to TPACK.}

Researched had interviewed three science teachers regarding their perception on the integration of ICT in relation to TPACK, while the interview guideline questions were constructed based on the results of the survey analysis. The findings in this section are thematic and explained (see Table V). The study consists of four items of the theme, namely, type of ICT used, pedagogy of teaching, content knowledge and the purpose of ICT integration.

The type of ICT used is defined by 26 statements which may be related to the constructs of TK, TPK, TCK and TPACK. The type of ICT used varies from hardware to Web 2.0 software used by science teachers. Most of the teachers revealed that their technology skills were at a good stage, most of them being able to set up an LCD and a laptop without the aid of a technician. On the other hand, the pedagogy of teaching was also discussed. Some pedagogy, such as students-centred approach, was concerned with the use of ICT. In the interview, the science teachers also showed their expert knowledge of science in the classroom. They will recognise which topic in science curriculum was difficult for their students and integrated the ICT to help boost their understanding. One of the participants, Mr. Aaron, said that his students had always misunderstood the difference between light and pigment. Mr. Aaron would also integrate the technology to improve student comprehension. Integration may be essential in the instruction and related to the constructs of CK, TCK and TPACK. Lastly, 17 statements from the participants mentioned about the purpose of the ICT integration in their classroom. They mentioned that all of these helped student's involvement in the classroom, for example, the use of Kahoot apps in the classroom assessment. It has the ability to make learning enjoyable as peers engage in a fun learning climate.

\begin{tabular}{|c|c|c|c|}
\hline Theme & $\begin{array}{l}\text { Statement } \\
\text { Frequency }\end{array}$ & $\begin{array}{c}\text { Representative } \\
\text { Statement }\end{array}$ & Description \\
\hline $\begin{array}{l}\text { Type of ICT } \\
\text { used }\end{array}$ & 26 & $\begin{array}{l}\text { 'My way is that I } \\
\text { will teach using } \\
\text { power point, } \\
\text { video... ..actually } \\
\text { I got the video } \\
\text { earlier from } \\
\text { YouTube or } \\
\text { Facebook and } \\
\text { somewhere taken } \\
\text { from a CD'. } \\
\text { (Madam B) }\end{array}$ & $\begin{array}{l}\text { Information on } \\
\text { technology } \\
\text { integration that } \\
\text { may relate to } \\
\text { TK, TCK, } \\
\text { TPK and } \\
\text { TPACK }\end{array}$ \\
\hline $\begin{array}{l}\text { Pedagogy of } \\
\text { teaching }\end{array}$ & 9 & $\begin{array}{l}\text { 'I want to ask } \\
\text { what they see and } \\
\text { try to tell me } \\
\text { where the natural } \\
\text { phenomena are or } \\
\text { where all these } \\
\text { things can be seen } \\
\text { in daily life. From } \\
\text { here it is better to } \\
\text { explain terms } \\
\text { such as reflection } \\
\text { of light, refraction } \\
\text { of light or } \\
\text { scattering of } \\
\text { light'. (Mr. A) }\end{array}$ & $\begin{array}{l}\text { Information on } \\
\text { the pedagogy } \\
\text { used that can } \\
\text { be integrated } \\
\text { with ICT (PK, } \\
\text { TPK, TPACK) }\end{array}$ \\
\hline $\begin{array}{l}\text { Content } \\
\text { knowledge }\end{array}$ & 8 & $\begin{array}{l}\text { 'With the } \\
\text { availability of } \\
\text { technology, I can } \\
\text { further explain the } \\
\text { abstract idea or } \\
\text { see more of that } \\
\text { abstract object } \\
\text { with animated } \\
\text { video. The same } \\
\text { goes for those } \\
\text { processes, and the } \\
\text { use of technology } \\
\text { makes it easier to } \\
\text { see'. (Ms._S) }\end{array}$ & $\begin{array}{l}\text { Information on } \\
\text { how the } \\
\text { content of } \\
\text { science can be } \\
\text { taught through } \\
\text { ICT } \\
\text { integration- } \\
\text { (CK, TCK, } \\
\text { TPACK). }\end{array}$ \\
\hline $\begin{array}{l}\text { Purpose of } \\
\text { ICT } \\
\text { integration- }\end{array}$ & 17 & $\begin{array}{l}\text { 'So normally I'm } \\
\text { just going to do a } \\
\text { quiz with } \\
\text { Kahoot...my } \\
\text { students have a lot } \\
\text { of fun, and they're } \\
\text { going to race to } \\
\text { answer my } \\
\text { questions with } \\
\text { Kahoot'. (Madam } \\
\text { B) }\end{array}$ & $\begin{array}{l}\text { Information on } \\
\text { the purpose of } \\
\text { using ICT } \\
\text { integration as a } \\
\text { lesson } \\
\text { instruction- }\end{array}$ \\
\hline
\end{tabular}

\section{DISCUSSION}

In this study, the science teachers scored different means for all the different constructs with their lowest mean score being 3.13 for the TK construct while highest mean score being 3.94 for the $\mathrm{CK}$ construct, as presented in Table II. The 
high mean scores of teachers suggested that they agreed to most of the things on the different constructs and therefore had a strong understanding of their knowledge of the construct of TPACK. The evidence points to the fact that the teachers had more expertise in the frameworks of 'traditional' material and pedagogy. This may be because historically teacher education systems can be well trained with an emphasis on CK construct and PK construct. Although the science teachers had a low mean score for the TK construct, they did have higher mean scores for other constructs related to technology (TCK, TPK and TPACK) compared to the TK construct. The findings from this study are consistent with [33], who also found that science teachers had low score for the TK construct but high scores in other constructs. This suggested that they had been able to successfully integrate technology into teaching or they were confident teaching despite having limited TK construct.

The relationship between science teachers' TPACK and ICT integration has also been analysed. The results of this research are close to the research results of [34], which confirmed that there was a positive relationship between TPK construct, TPACK construct and ICT achievement among pre-service teachers. While their success in technology during their studies is not a guarantee that they can incorporate technology after they have taught at school later, the experience they acquire is valuable for their career growth in the future. As a result, the findings of this study have shown that technology-related constructs have a moderately positive relationship with the ICT integration experience of science teachers relative to other constructs that only display a low positive relationship. However, such results are not shocking, as it can be argued that not all teachers are confident in the practice of ICT integration based on the level of TPACK that has been demonstrated at a moderate stage.

For the discussion of multiple regression, the regression analyses indicated that the TPACK and TCK constructs were the significant contributors to the integration of ICT. These constructs accounted for about $48 \%$ of the variance in the integration of ICT. Although the TPACK construct was the single largest contributor, the stepwise regression indicated that the TCK construct also made a significant contribution to the variance in the model. The evidence seen in this study replicates the study findings of [35], which have stated that the TPACK variables are among the effective variables in contributing to the process of technology integration by teachers compared to other variables. Similarly, the findings of the study of [36] also reported that TPACK constructs are a major contributor to the use of information and communications technology among trainee teachers during teaching practice. Once again, this has shown that the TPACK model is a collection of information developed and is capable of being a strong predictor of technology integration in teaching by using various research models and samples. All of these variables may be added to the current literature list.

Qualitatively, the findings support the results of the quantitative findings. All the participants who are science teachers talked about how they integrate the ICT tools in cooperation with pedagogy in science lesson. All the purpose of ICT integration seems to influence the TK, TPK, TCK and TPACK constructs. The in-depth information elaborated that despite having a low level of technology-based knowledge, the science teachers perceived that technology is to improve instruction.

\section{LIMITATION}

The findings of this study were collected using self-reported data, which has the potential for legitimate self-assessment to distort the results. On the other hand, the research included a limited number of science teachers; thus, the generalization of the findings to other populations should be performed with caution.

\section{IMPLICATION AND FUTURE RESEARCH}

The findings of this study have consequences for the professional development or professional training of teachers. Although the current professional developments have not officially adopted the TPACK framework as the basis for evaluating the integration of ICT based on TIP model, science teachers need to build an adequate level of TPACK in order to better incorporate ICT into their specific subject area. TPACK is an important knowledge base for the professional competence of teachers in the service sector. As a result, the consequences of the increased demands for technology to be incorporated into the pedagogical and content training of teachers put the pressure on science teachers with substantial levels of TPACK exposure and practice. Future research can be considered to be extended to a broader scale of science teachers across Malaysia's national schools. A study can also be extended to other countries in the field.

\section{CONCLUSION}

The findings of this study have shown that Malaysian secondary science teachers have strong expectations of their comprehension of TPACK constructs. There have been positive associations between the TPACK construct and ICT integration through the lens of TPACK. The constructs TPACK and TCK were established as key predictors of ICT integration among the science teachers. This may help researchers to better understand the contribution of technology-based knowledges toward the integration of ICT. Furthermore, both quantitative and qualitative findings also revealed that the technology-based knowledge had contributed to the ICT integration. In order to increase the ability of science teachers to integrate ICT in their classroom, professional trainings are suggested to hold in relation to technology-based knowledge in instruction.

This paper shed light on Malaysian secondary school science teachers' perceptions of their understanding of the various constructs of TPACK. The paper shed more light on the correlations between the various constructs toward the integration of ICT and indicated the constructs that are major predictors of Malaysia secondary school science teachers in the integration of ICT. 


\section{CONFLICT OF INTEREST}

We certify that there is no actual or potential conflict of interest in relation to this article.

\section{AUTHOR CONTRIBUTIONS}

The first author conducted the research and wrote the research paper. The second author revisited, reviewed and revised the whole paper accordingly. At the same time, he also gave the input in the technical aspects and contributed in educational perspectives. All authors had approved the final version.

\section{ACKNOWLEDGEMENT}

This paper is part of the first author's doctoral study at the University of Malaysia Sabah. The study was supported by the Ministry of Education, Malaysia, under the Federal Training Grant.

\section{REFERENCES}

[1] J. N. Oigara, "Integrating technology in Teacher education programs," Research Perspectives and Best Practices in Educational Technology Integration, 2013, ch. 2, pp. 28-43.

[2] I. N. Umar and A. S. A. Hassan, "Malaysian teachers' levels of ICT integration and its perceived impact on teaching and learning," Procedia-Social and Behavioral Sciences, vol. 197, pp. 2015-2021, 2015.

[3] K. D. Witte and N. Rogge, "Does ICT matter for effectiveness and efficiency in mathematics education?" Computer \& Education, no. 75 , pp. 173-184, 2014

[4] L. Archambault and K. Crippen, "Examining TPACK among K-12 online distance educators in the United States," Contemporary Issues in Technology and Teacher Education, vol. 9, no. 1, pp. 71-88, 2009.

[5] K. A. Owusu, C. Lindsey, and A. Chris, "Assessing New Zealand high school science teachers' technological pedagogical content knowledge," Journal of Computers in Mathematics and Science Teaching, vol. 34, no. 3, pp. 345-373, 2015.

[6] M. L. Niess, "Investigating TPACK: Knowledge Growth in Teaching with Technology," Journal of Educational Computing Research, vol. 44, no. 3, pp. 299-317, 2011.

[7] G. Chittleborough, "Learning how to teach chemistry with technology: Pre-service teachers' experiences with integrating technology into their learning and teaching," Journal of Science Teacher Education, vol. 25, no. 4, pp. 373-393, 2014.

[8] R. M. Pringle, K. Dawson, and A. D. Ritzhaupt, "Integrating science and technology: Using technological pedagogical content knowledge as a framework to study the practices of science teachers," Journal of Science Education and Technology, vol. 24, no. 5, pp. 648-662, 2015.

[9] P. Mishra and M. Koehler, "Technological pedagogical content knowledge: A framework for teacher knowledge," The Teachers College Record, vol. 108, no. 6, pp. 1017-1054, 2006.

[10] M. Y. Tee and S. S. Lee, "From socialisation to internalisation: Cultivating technological pedagogical content knowledge through problem-based learning," Australasian Journal of Educational Technology, vol. 27, no. 1, pp. 89-104, 2011.

[11] Y. J. Joo, S. Park, and E. Lim, "Factors influencing preservice teachers' intention to use technology: TPACK, teacher self-efficacy, and technology acceptance model," Journal of Educational Technology and Society, vol. 21, no. 3, pp. 48-59, 2018.

[12] Y. H. Chen and S. J. Jang, "Exploring the relationship between self-regulation and TPACK of Taiwanese secondary in-service teachers," Journal of Educational Computing Research, vol. 57, no. 4, pp. 978-1002, 2018.

[13] M. T. Khor and H. L. Lim, "Technology pedagogy and content knowledge (TPACK) among mathematics' teachers in primary school," Jurnal Pendidikan Sains dan Matematik Malaysia, vol. 4, no. 1, pp. 29-43, 2014.

[14] M. Y. Mai and M. Hamzah, "Primary science teachers' perceptions of technological pedagogical and content knowledge (TPACK) in Malaysia," European Journal of Social Science Education and Research, vol. 3, no. 2, pp. 167-179, 2016.
[15] L. S. Shulman, "Those who understand: Knowledge growth in teaching," Educational Researcher, vol. 15, no. 2, pp. 4-14, 1986.

[16] R. Sheffield, E. Dobozy, D. Gibson, J. Mullaney, and C. Campbell, "Teacher education students using TPACK in science: A case study," Educational Media International, pp. 1-12, 2015.

[17] B. Martin, "Faculty technology beliefs and practices in teacher preparation through a TPaCK lens," Education and Information Technologies, vol. 23, no. 5, pp. 1775-1788, 2018.

[18] M. B. Horzum, "An investigation of the technological pedagogical content knowledge of pre-service teachers," Technology, Pedagogy and Education, vol. 22, no. 3, pp. 303-317, 2013.

[19] J. Tondeur, R. Scherer, F. Siddiq, and E. Baran, “A comprehensive investigation of TPACK within pre-service teachers' ICT profiles: Mind the gap," Australasian Journal of Educational Technology, vol. 33, no. 3, pp. 46-60, 2017.

[20] T. L. Lau, "Opportunities and challenges faced by private higher education institution using the TPACK model in Malaysia," Procedia-Social and Behavioral Sciences, vol. 91, pp. 294-305, 2013.

[21] M. Tchoshanov, M. D. Cruz, K. Huereca, K. Shakirova, L. Shakirova \& E. N. Ibragimova, "Examination of lower secondary mathematics teachers' content knowledge and its connection to students' performance," International Journal of Science and Mathematics Education, vol.15, no. 4, pp. 683-702, 2017.

[22] S. Willermark, "Technological pedagogical and content knowledge: A review of empirical studies published from 2011 to 2016," Journal of Educational Computing Research, vol. 56, no.3, pp. 315-343, 2018.

[23] C. Angeli and N. Valanides, "Epistemological and methodological issues for the conceptualization, development, and assessment of ICT-TPCK: Advances in technological pedagogical content knowledge (TPCK)," Computers \& Education, vol. 52, no. 1, pp. 154-168, 2009.

[24] T. C. Lin, C. C.Tsai, C. S. Chai, and M. H. Lee, "Identifying science teachers' perceptions of technological pedagogical and content knowledge (TPACK)," Journal of Science Education and Technology, vol. 22, no. 3, pp. 325-336, 2013

[25] J. W. Creswell, A Concise Introduction to Mixed Methods Research, SAGE Publications, 2014, pp. 63-98.

[26] L. Cohen, L. Manion, and K. Morrison, Research Methods in Education $8^{\text {th }}$ ed, NY: Routledge, 2018, pp.334-360.

[27] D. A. Schmidt, E. Baran, A. D. Thompson, P. Mishra, M. J. Koehler, and T. S. Shin, "Technological pedagogical content knowledge (TPACK): The development and validation of an assessment instrument for preservice teachers," Journal of Research on Technology in Education, vol. 42, no. 2, pp. 123-149, 2009.

[28] Z. Hosseini and A. Kamal, "Questionnaire to measure perceived technology integration knowledge of teachers (TPCK)," in Proc. from International Conference of Advanced Information System, E-Education and Development, 2012.

[29] M. D. Roblyer, Integrating Educational Technology into Teaching, $4^{\text {th }}$ ed, NJ: Pearson Merrill Prentice Hall, 2006.

[30] K. F. Punch and A. Oancea, Introduction to Research Methods in Education, SAGE Publication, 2014, ch. 12, pp. 285-308.

[31] J. F. Hair and M. Page, Essentials of Business Research Methods, NY: Routledge, 2015, pp. 245-255.

[32] B. G. Tabachnick and L. S. Fidell, Using Multivariate Statistics, 6th ed, NJ: Pearson Education, 2013, ch 6, pp. 117-196.

[33] D. Setyorini, Astija, and A. Kasim, "The high school biology teachers knowledge in Palu city to framework the technological pedagogical and content knowledge," Journal of Physics: Conference Series, vol. 1233, no. 1, p. 012013, IOP Publishing, 2019.

[34] M. S. Khine, N. Ali, and E. Afari, "Exploring relationships among TPACK constructs and ICT achievement among trainee teachers," Educ Inf Technol, vol. 22, pp. 1605-1621, 2017.

[35] O. Uslu, "Factors associated with technology integration to improve instructional abilities: A path model," Australian Journal of Teacher Education, vol. 43, no. 4, pp. 31-50, 2018.

[36] A. Habibi, F. D. Yusop, and R. A. Razak, "The role of TPACK in affecting pre-service language teachers' ICT integration during teaching practices: Indonesian context," Education and Information Technologies, vol. 25, no. 3, pp. 1929-1949, 2020.

Copyright (C) 2021 by the authors. This is an open access article distributed under the Creative Commons Attribution License which permits unrestricted use, distribution, and reproduction in any medium, provided the original work is properly cited ( $\underline{\mathrm{CC} \mathrm{BY} 4.0})$. 


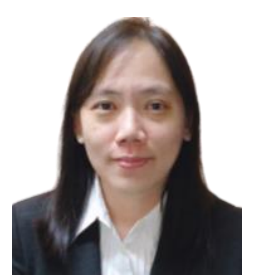

Chieng You Eng is a PhD candidate in computer education at the University of Malaysia Sabah. Her research interests include integrating information and communications technology (ICT) into teaching and learning and educational technology in subject science.

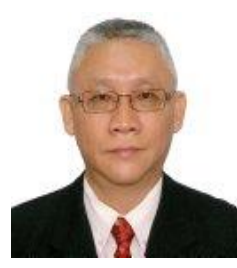

Tan Choon Keong is an associate professor at the Faculty of Psychology and Education, University of Malaysia Sabah. His research interests include e-learning, computer and multimedia in education and creativity in education. 